\title{
Genetic and morphological differentiation between isolated Polish populations of "glacial relict", an endangered butterfly, Oeneis jutta (Lepidoptera: Nymphalidae)
}

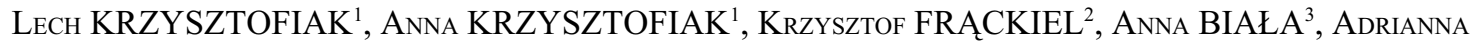 \\ KILIKOWSKA ${ }^{3}$ and JERZY SELL ${ }^{3 *}$ \\ ${ }^{1}$ Wigry National Park, Krzywe 82, 16-402 Suwałki, Poland; e-mail: krzysztofiak.lech@gmail.com \\ ${ }^{2}$ Biebrza National Park, Osowiec-Twierdza 8, 19-110 Goniądz, Poland; e-mail: frackiel@csk.pl \\ ${ }^{3}$ Department of Genetics, University of Gdańsk, P.O. Box 284, 80-958 Gdańsk 50, Poland; e-mail: sell@biotech.ug.gda.pl
}

Key words. Augustowska Primeval Forest, glacial relict, Jutta Arctic, Lepidoptera, mtDNA, Oeneis jutta, peripheral populations, Satyrinae, Wigry National Park

\begin{abstract}
This is the first study of the morphological and molecular variation in two peripheral populations of the butterfly Jutta Arctic, Oeneis jutta, a glacial relict species endangered by the fragmentation of its habitat in Poland. An analysis of the morphological characteristics indicates that both Polish populations are similar but differ significantly in some characteristics. Levels of genetic variation were assessed using mitochondrial cytochrome oxidase subunit I (COI) and NADH dehydrogenase subunit 5 (ND5) gene fragments together with a segment of the mtDNA control region $(\mathrm{CR})$ and a nuclear elongation factor-1 $\alpha(E F-1 \alpha)$ gene sequence. In addition, the pattern of molecular variation in specimens from eastern and northern Europe was examined. Interestingly, the analysis of variation in a 932-bp sequence of the nuclear $E F-1 \alpha$ gene in representatives of the populations studied revealed a relatively higher level of diversity than that of mitochondrial genes. There was evidence of divergence between the peripheral populations and lack of gene flow between them. The two closely situated populations had a high $\Phi_{S T}$ value $(0.69)$, which clearly indicates their isolation. These populations appear to be demographically independent breeding units, with distinctive allele frequencies and consequently should be recognized as separate units for management and conservation. The preliminary results are in accord with an a priori subdivision based on collection areas and suggest that habitat fragmentation has affected the genetic diversity and structure of these populations.
\end{abstract}

\section{INTRODUCTION}

Range-wide patterns in the genetic diversity of species are recognized as being in part a consequence of glacial and postglacial range changes (Hewitt, 1996, 2001, 2004) shaped by demographic and genetic stochasticity. The "centre-periphery hypothesis" predicts that populations at the margins of the distribution are more prone to extinction and generally less diverse than those at the centre (Hampe \& Petit, 2005, and references therein). Peripheral populations occur near the outer boundary of the geographical range of a species and are often relatively small and isolated from the central populations. Reduced gene flow, small population size and founder effects will promote genetic drift and result in reduced genetic variation and increased differentiation of peripheral populations (Lesica \& Allendorf, 1995, and references therein). Genetic impoverishment is usually assumed to be an effect of genetic erosion within isolated populations in fragmented environments. Lack of viability and adaptability due to reduced genetic diversity within populations is recorded in many case studies (Schmitt \& Hewitt, 2004, and references therein). However, some authors consider peripheral populations important for the evolutionary future of species (a source of future speciation events) as they increase their ability to evolve new adaptations (Lesica \& Allendorf, 1995). Thus, species at the edge of their range, in some cases, should be conserved.
The population structure of butterfly species within fragmented habitats, depending on the connectedness among populations and dispersal capacity, resembles that of either a classic metapopulation or a source-sink population (Sigaard et al., 2008). Low levels of dispersal are expected to lead to genetic differentiation of subpopulations. In the present study, we investigated the levels of morphological and genetic variation in two Polish populations of the endangered butterfly, the Jutta Arctic (Oeneis jutta), at the southern edge of its range.

Oeneis jutta (Hübner, 1806) is the only representative of the genus Oeneis Hübner, 1819 in Poland. Nowadays this genus is included in the subfamily Satyrinae, within the family Nymphalidae. It is a holarctic species found in northern regions of the entire northern hemisphere, inhabiting coniferous forests and peat bogs in northern Eurasia, from Scandinavia through northern Europe, Siberia, Mongolia, and China to the Chukchi Peninsula and North America (Buszko, 1993; Buszko \& Masłowski, 2008; Lukhtanov \& Eitschberger, 2000; Scott, 1986). In Europe, O. jutta is present in Poland, Sweden, Norway, Finland, Russia, Belarus, Latvia, Estonia, and Lithuania (Gerasimov \& Pljushtch, 2005; Henriksen \& Kreutzer, 1982; Ivinskis \& Rimšaite, 2004; Kudrna, 2002). The southern border of the range of $O$. jutta is in Poland and Belarus. The largest number of the specimens is found in the north, while at the southern periphery of the distributional range it occurs locally and in small numbers.

\footnotetext{
* Corresponding author
} 
Oeneis jutta is a polytypical species consisting of numerous local populations, which frequently clearly differ from each other. This species comprises as many as 15 subspecies. In Europe, the subspecies, Oeneis jutta jutta [Hübner, (1806)], inhabits the northern part of the continent. Oeneis jutta is a boreal species, inhabiting raised and transitory bogs covered by dwarf pines and sparse marshland forests. In Poland, it is a relict species of the last ice age. Due to its origin and specific environmental requirements this species is found only locally. It is rarely observed and its existence is perilously endangered. Oeneis jutta was not placed under legal protection until 2001, (Enactment of the Ministry of the Environment of 2001). Based on a new enactment of the Minister of the Environment (2004), $O$. jutta is now included in a group of species subject to and requiring the highest level of protection. The species is also on the "Red List of Threatened Animals in Poland" (Głowaciński, 2002) and in the "Polish Red Data Book of Animals" (Głowaciński \& Nowacki, 2004), and designated a critically endangered species. Despite this, there is no previous assessment of the population status of this species. In the present study, the levels of differentiation and extent of gene flow between closely located peripheral populations of $O$. jutta at the southern limit of its range were investigated, using mtDNA, nuclear markers, and morphological characters. To our knowledge, this is the first study investigating the effect of habitat fragmentation on the genetic diversity of this "glacial relict".

\section{MATERIAL AND METHODS}

\section{Occurrence of Oeneis jutta in Poland}

The result of intensive field research revealed the presence of $O$. jutta only at two sites in the north-eastern region of Poland. The first is located at Suche Bagno, a nature reserve within the Wigry National Park. The site is 28.5 ha in extent and is covered by Ledo-Sphagnetum magellanici, forest raised bog community, Vaccinio uliginosi-Pinetum, bog coniferous forest, and transitional forms between these habitats. This environment is characterized by species impoverishment and a monotonous landscape. Observations on the flight pattern of $O$. jutta in this area indicates that this butterfly is present at various levels of abundance within an approximately 10 ha area of a raised woodland peatbog.

The second area is in the south part of the Augustowska Primeval Forest located between two villages: Wyżarne, to the west and Skieblewo, to the east. The entire terrain is a unique mosaic of marshlands and peatbogs. Here there are $V$. uliginosi-Pinetum bog coniferous forest (in various stages of maturity), fragments of Ledo-S. magellanici forest raised bog community and expanses of boreal bog birch and alder woods. The butterfly was observed in an approximately 50 ha area, both on a raised peatbog with pines and moss-covered birch trees and at the edges of the bog forest.

The distance between both these sites is approximately 30.5 $\mathrm{km}$, and is covered by high density Augustowska Primeval Forest, lakes, and small towns.

\section{Morphological analysis}

Mark and recapture method was carried out within the sites inhabited by $O$. jutta. At Suche Bagno, each count was carried out simultaneously at 6 areas, $10 \mathrm{~m}$ wide and $500 \mathrm{~m}$ long, while at Skieblewo, the count was of butterflies observed within a 10 $\mathrm{km}$ long transect. An assessment of the local population size was performed using both a direct method, the number of butterflies observed, and by applying the Chapman modification of the Lincoln-Petersen formula (Chapman, 1951) to the mark and recapture results.

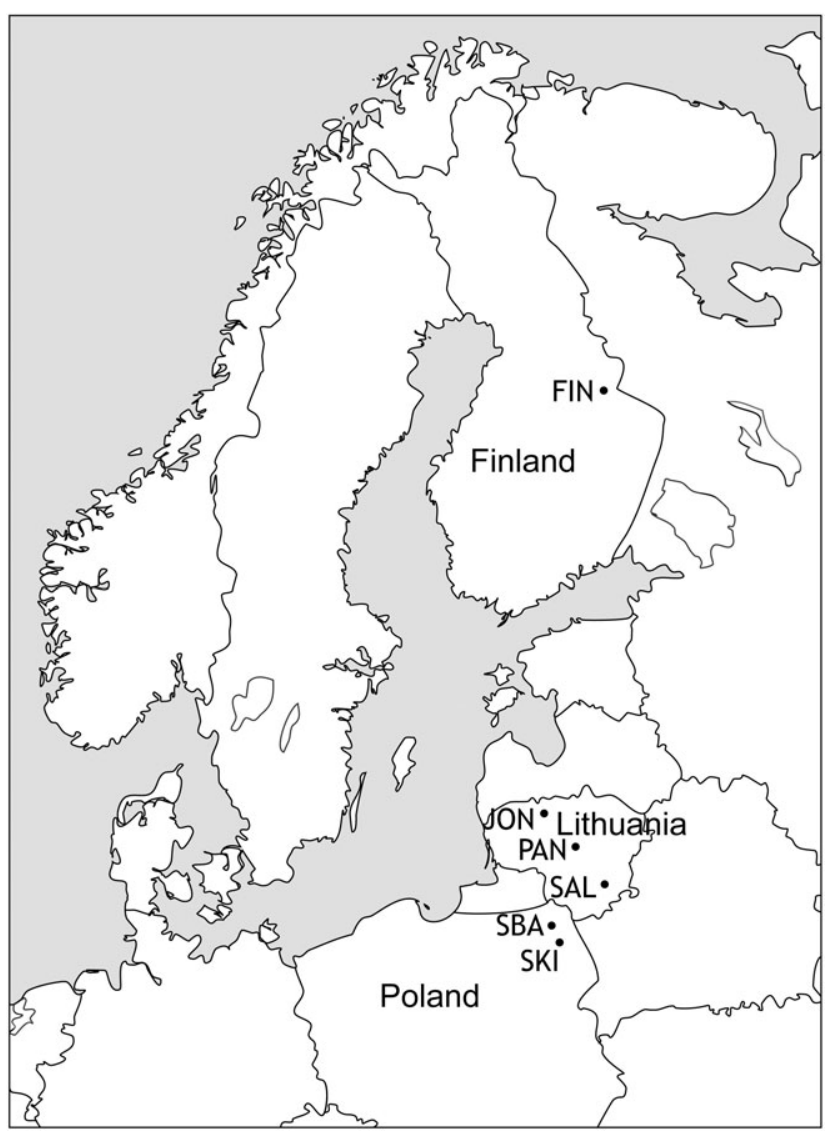

Fig. 1. Location of the populations of Oeneis jutta sampled for this study. SBA - Suche Bagno; SKI - Skieblewo; PAN Panevezys; SAL - Salcinnikai; JON - Joniskis; FIN - Finnish population.

The following characteristics were used in the morphological analysis: the length of the fore-wing measured from the wing base to the end of the $\mathrm{r} 1$ vein, the width of the forewing measured from the end of the $\mathrm{r} 1$ vein to the end of the cu2 vein, the length of the hind-wing measured from the wing base to the end of the $\mathrm{m} 2$ vein, the width of the hind-wing measured from the end of the $\mathrm{r} 1$ vein to the end of the cu2 vein, the surface of the fore-wing, surface of the hind-wing, size of the black and greyish yellow eye spots on the fore-wings and hind-wings, and the width of the thorax. Statistical significance of the differences revealed by the morphological analysis was assessed using $t$-tests for independent and dependent samples. All statistics were computed using STATISTICA (StatSoft Inc., Tulsa, OK, USA) software.

\section{Molecular analysis}

Samples of $O$. jutta were collected from two Polish populations: Suche Bagno $(\mathrm{N}=20)$ and Skieblewo $(\mathrm{N}=17)$. In addition, specimens were obtained from Salcinnikai, Panevezys, and Joniskis districts (Lithuania) $(\mathrm{N}=5$ each), and from Finland ( $\mathrm{N}$ $=4)$. The location of the collection sites are shown in Fig. 1 . The animals were brought either alive or in dry ice to the laboratory, where they were stored frozen at $-70^{\circ} \mathrm{C}$. The specimens obtained from Finland and Joniskis were dried.

Genomic DNA was extracted from a single leg or thoracic tissue of each individual using a Genomic Mini kit (A\&A Biotechnology, Gdańsk, Poland). Fragments of mtDNA: cytochrome oxidase subunit I $(C O I)$ gene $(\sim 660 \mathrm{bp})$ and NADH dehydrogenase subunit 5 (ND5) ( $\sim 830 \mathrm{bp})$ were amplified with 
primers HCO-1490 and LCO-2198 (Folmer et al., 1994) and V1 and A1 (Yagi et al., 1999), respectively, using the following PCR conditions: 45 cycles of $45 \mathrm{~s}$ each at $94^{\circ} \mathrm{C}$ and $54^{\circ} \mathrm{C}$ followed by $50 \mathrm{~s}$ at $72^{\circ} \mathrm{C}$. The amplification was preceded by 7 min at $94^{\circ} \mathrm{C}$ and terminated with $10 \mathrm{~min}$ at $72^{\circ} \mathrm{C}$. DNAs extracted from dried Finland and Joniskis specimens were not suitable for PCR amplification of ND5; therefore, they were excluded from further analyses based on composite mtDNA haplotypes.

Mitochondrial DNA control region (CR) sequence variation was examined only in both Polish populations. CR products, amplified with the primer pair J6 (Zhang et al., 1995) and Lep12S (Vila \& Björklund, 2004), were sequenced using SeqLepMet and LepAT2B as internal primers (Vila \& Björklund, 2004).

The variation in the nuclear elongation factor- $1 \alpha(E F-1 \alpha)$ gene sequence from representatives of all the populations studied was examined. To amplify a fragment of the nuclear $E F-1 \alpha$ gene, Ef44(f)-240 and EfrcM4(r)-1351 primers were used (Monteiro \& Pierce, 2000). The PCR reaction consisted of the following steps: $95^{\circ} \mathrm{C}$ initial denaturation for $5 \mathrm{~min}, 35$ cycles of $1.5 \mathrm{~min}$ at $94^{\circ} \mathrm{C}, 1.5 \mathrm{~min}$ at $58^{\circ} \mathrm{C}$, and $1,5 \mathrm{~min}$ at $72^{\circ} \mathrm{C}$, followed by final elongation for $5 \mathrm{~min}$ at $72^{\circ} \mathrm{C}$. All PCRs were done using a PTC 100 Thermocycler (MJ Research Inc., Waltham, MA, USA).

The amplified products were purified using exonuclease I (10 $\mathrm{U} / \mu \mathrm{l}, \mathrm{USB})$ and alkaline phosphatase SAP (1 U/ $\mu 1$, USB) treatment according to the manufacturer's guidelines, and sequenced directly in both directions using the same primers as used at the amplification stage. BLAST (Altshul et al., 1990) searches were performed to verify the quality of the sequencing. Then the sequences were aligned using ClustalX (Thomson et al., 1997), and the alignment improved using BioEdit (Hall, 1999).

\section{Data analysis}

Haplotypes were identified and their relative frequency within populations calculated using ARLEQUIN version 2.000 (Schneider et al., 2000). The sequences of all haplotypes were deposited in GenBank under accession numbers GQ351504GQ351514. Genetic diversity within populations was measured as haplotype diversity $h(\mathrm{Nei}, 1987)$ and nucleotide diversity $\pi$ (Nei, 1987). Genetic divergences between pairs of samples were estimated using $\Phi$ statistics ( $\Phi_{S T}$ based on haplotype frequencies and molecular divergence, using pairwise differences). $P$ values were obtained by multiple permutations (1000) of the original data set. The spatial distribution of genetic variation was examined using an analysis of molecular variance (AMOVA; Excoffier et al., 1992). All statistics were computed using ARLEQUIN.

\section{RESULTS}

\section{Population size and gender structure}

The results of the direct butterfly counts at the Suche Bagno study site were: 112 and 122 individuals in 2006 and 99, 141, and 162 in 2007. Taking into account the highest number of butterflies recorded, it may be accepted that this population totals at least 162 individuals. At Skieblewo, 23 individuals were recorded in 2006 and 53 in 2007.

The population counts of butterflies at Suche Bagno in 2007 and 2008 were carried out during the first decade of June using mark and recapture. The results indicate that the population size of $O$. jutta was 371 individuals in 2007 and 298 individuals in 2008.

During the study period (2006-2008) the earliest flights of adult butterflies were observed in the first week of May at

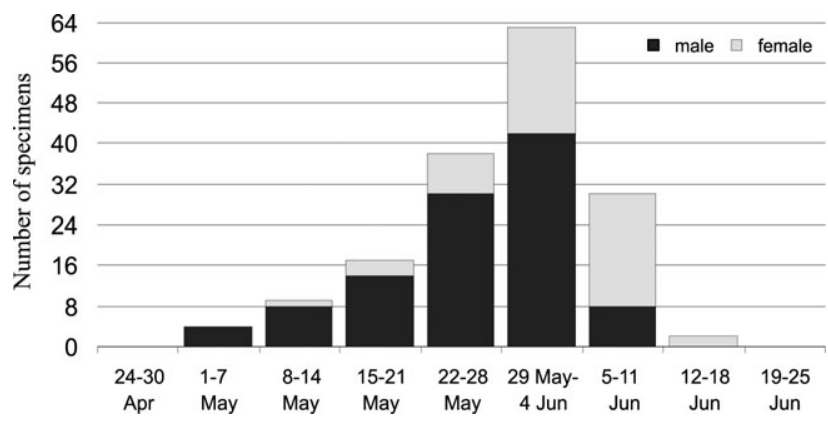

Fig. 2. Seasonal activity of adult male and female Oeneis jutta recorded in the field.

Suche Bagno. Initially there were only males, which appeared 7-9 days earlier than the females (protandry). As time went by the sex structure of the population changed (Fig. 2). The greatest numbers of butterflies were present between the beginning of May and beginning of June and during this period males dominated. At the end of the first week of June, the number of adults rapidly decreased and females began to prevail among the flying individuals. The last butterflies (females) were recorded in the middle of June.

\section{Morphological differences between the populations of Oeneis jutta at Suche Bagno and Skieblewo}

The analysis indicates that the $O$. jutta populations at Suche Bagno and Skieblewo, although similar, do differ significantly in some morphological characteristics. The differences are in the width of the thorax of the males, the number of greyish yellow spots on the fore-wings of females and males, the size of black spots on the fore-wings as well as the greyish yellow spots on the fore-wings and hind-wings of females. However, there are also statistically significant differences in wing size.

The average surface area of the wings of males at Skieblewo was larger (but not statistically so; $P>0.05$ ) than that of the males at Suche Bagno, in both the area of the fore-wings 262.1 \pm 24.9 vs. $248.3 \pm 18.6 \mathrm{~mm}^{2}$ and hind-wings $283.2 \pm 22.2$ vs. $259.2 \pm 13.6 \mathrm{~mm}^{2}$, respectively (means and standard deviations). In contrast, the females at Suche Bagno had both larger forewings $\left(281.2 \pm 18.7 \mathrm{~mm}^{2}\right)$ and hind-wings $\left(284.6 \pm 17.5 \mathrm{~mm}^{2}\right)$ than those at Skieblewo $\left(266.8 \pm 33.6\right.$ and $258.6 \pm 29.9 \mathrm{~mm}^{2}$, respectively).

The differences in the wing length and width of butterflies from both populations were less clear and statistically insignificant $(P>0.05)$ but the average values for males were higher at Skieblewo and for females at Suche Bagno. The average forewing and hind-wing lengths of females at Skieblewo were 26.4 $\pm 1.2 \mathrm{~mm}$ and $21.9 \pm 0.8 \mathrm{~mm}$, respectively. Wings of males were of similar length, fore-wings $26.9 \pm 0.9 \mathrm{~mm}$ and hindwings $22.7 \pm 0.9 \mathrm{~mm}$ long. The average width of the forewings of females was $16.4 \pm 1.1 \mathrm{~mm}$ and of males $16.9 \pm 0.7 \mathrm{~mm}$. The width of the hind-wings was insignificantly smaller in females $(15.7 \pm 1.2 \mathrm{~mm})$ than in males $(16.7 \pm 0.7 \mathrm{~mm})$. The morphological characteristics of the butterflies from Suche Bagno were relatively homogeneous (the coefficient of variation, $\mathrm{CV}$, was below $10 \%$ for all the characteristics). For females, the length of the fore-wings was $27.8 \pm 1.1 \mathrm{~mm}$ and hind-wings $22.5 \pm 0.8$ $\mathrm{mm}$. The wings of males were somewhat shorter with the forewings measuring $26.1 \pm 1.1 \mathrm{~mm}$ and hind-wings $21.6 \pm 0.8 \mathrm{~mm}$. Differences between the length of the wings of males and females were statistically significant $(P<0.05)$ for both the fore-wings and hind-wings. The average width of the fore-wings of females was $16.7 \pm 0.6 \mathrm{~mm}$ and males $16.2 \pm 0.5 \mathrm{~mm}$. The hind-wings of females were narrower $(16.2 \pm 0.7 \mathrm{~mm})$ than 
TABLE 1. Haplotype designation and variable nucleotide positions of ND5 $(16 ; 237)$ and COI (1058) gene sequences among the $5 \mathrm{mtDNA}$ haplotypes found in Oeneis jutta populations. Dots indicate identical bases. The entire sequence of haplotype A was deposited in GenBank, accession no.'s: GQ351504, GQ351510.

\begin{tabular}{cccc}
\hline \multirow{2}{*}{ Haplotype } & \multicolumn{3}{c}{ Nucleotide position } \\
\cline { 2 - 4 } & 16 & 237 & 1058 \\
\hline A & $\mathrm{A}$ & $\mathrm{C}$ & $\mathrm{C}$ \\
$\mathrm{B}$ & $\mathrm{G}$ & $\cdot$ & $\mathrm{T}$ \\
$\mathrm{C}$ & $\mathrm{G}$ & $\cdot$ &. \\
$\mathrm{D}$ &. &. & $\mathrm{T}$ \\
$\mathrm{E}$ &. & $\mathrm{T}$ & $\mathrm{T}$ \\
\hline
\end{tabular}

those of males $(15.9 \pm 0.5 \mathrm{~mm})$. Only the difference between females and males in the width of the hind-wings was statistically significant $(P<0.05)$.

The width of the thorax of the butterflies in the two populations studied differed, with both females and males at Skieblewo having a wider thorax $(3.0 \pm 0.2$ and $3.5 \pm 0.5 \mathrm{~mm}$, respectively) than those at Suche Bagno $(2.7 \pm 0.4$ and $2.6 \pm 0.1 \mathrm{~mm})$. This difference was only statistically significant for males $(t=$ $-5.014, P<0.01)$.

Only for females was the size of the spots on wings significantly different. Black spots were considerably larger on the fore-wings of butterflies from Suche Bagno, with an area of 2.2 $\pm 1.1 \mathrm{~mm}^{2}$, than those from Skieblewo, with an area of $1.0 \pm 0.7$ $\mathrm{mm}^{2}(t=4.595, P<0.01)$. The average area of the spots on the wings of the females from Suche Bagno was more than double that of the spots on the wings of females from Skieblewo. This was also the case for the greyish yellow eye spots on the forewings, which with an area of $5.7 \pm 2.5 \mathrm{~mm}^{2}$ were also more than double the size of those of the females from "Suche Bagno" $(t=$ $6.160, P<0.01$ ), while on the hind-wings the area of the eye spots of $6.7 \pm 2.6 \mathrm{~m}^{2}$ was 1.7 times larger $(t=2.834, P<0.01)$ than that of the eye spots on the hind-wings of the Skieblewo females.

\section{Genetic diversity and population structure}

The sequence of a 610-bp segment of the COI gene was determined for 48 specimens of Oeneis jutta from six populations. In order to perform a more complete analysis of mtDNA sequences, a 816-bp segment of the ND5 gene of individuals from all but the Finnish and Joniskis populations was used. A total of three variable nucleotide sites and haplotypes were identified for the ND5 gene segment, while only one variable nucleotide position was found in the COI gene. Interestingly, one (A) of the two COI haplotypes was only found in the Suche Bagno (SBA) population, whereas the other was present in all the populations, including the Finnish population. By combining
TABLE 3. Pair-wise $\Phi_{S T}$ estimates between Oeneis jutta populations. Significance levels are indicated as $*$ if significant at $P$ $<0.001$, and in bold when non significant at $P>0.05$.

\begin{tabular}{cclcc}
\hline Haplotype & \multicolumn{1}{c}{ SBA } & \multicolumn{1}{c}{ SKI } & PAN & SAL \\
\hline SBA & 0.00000 & & & \\
SKI & $0.68703^{*}$ & 0.00000 & & \\
PAN & $\mathbf{0 . 7 3 5 9 4}$ & $0.83336^{*}$ & 0.00000 & \\
SAL & $0.73621^{*}$ & $\mathbf{0 . 7 1 5 0 9}$ & $-\mathbf{1 . 0 0 0 0 0}$ & 0.00000 \\
\hline
\end{tabular}

the variable positions for $\mathrm{COI}$ and $\mathrm{ND} 5$ gene segments a total of five unique mtDNA haplotypes were detected (Table 1). The length of the aligned mtDNA sequences was $1412 \mathrm{bp}$. As is general for mitochondrial DNA genes, the analyzed fragment is AT rich $(76.65 \%)$. All mutational changes were base pair substitutions and the transition: transversion (TS/TV) ratio was 2.0. Overall nucleotide diversity was low, ranging from 0.00 to $0.039 \%$, and haplotype diversity ranged from 0.00 to 0.40 (Table 2). Of the five composite haplotypes, $\mathrm{A}$ and $\mathrm{C}$ were found only in the SBA population (Table 2). Haplotype B was only found in the two Polish populations, Skieblewo (SKI) and SBA, and was the only one they shared, however, the frequency with which it occurred in the two populations significantly differed. Haplotype D was present in the Salcinnikai and Skieblewo populations, whereas haplotype $\mathrm{E}$ was limited to the Lithuanian populations and recorded at Panevesys and Salcinnikai.

Analysis of mtDNA variation using AMOVA revealed a high degree of genetic subdivision among the populations. Overall, $71 \%$ of the total diversity was accounted for by variation among populations $\left(\Phi_{S T}=0.709, P<0.001\right)$ and $21 \%$ by variation within populations. Overall in pairwise comparisons $\Phi_{S T}$ estimates ranged from negative to 0.833 (Table 3 ). The pairwise $\Phi_{S T}$ was insignificant between SBA-PAN; SKI-SAL, and PANSAL, most probably due to the low number of specimens in the Lithuanian samples.

In order to perform a more complete analysis of coding and noncoding mtDNA sequences, a 541-bp segment of the control region (CR; D-loop) was also sequenced for 10 individuals from each of the Polish populations. There was a lack of intrapopulation variability. However, a length polymorphism was observed in this fragment (data not shown). A short sequence variant was fixed in the SKI population and a longer variant, which resulted from an additional repetition of the ATTTTA motif, was found in all individuals from the SBA population. This motif is the next repeat in a sequence of similar tandem repeats, which is a characteristic feature of the CR.

Interestingly, the analysis of a 932-bp sequence of the nuclear $E F-1 \alpha$ gene in representatives of the populations studied revealed a relatively high level of diversity compared to the

TABLE 2. Distribution of mtDNA haplotypes in the Oeneis jutta populations, with relative frequencies, haplotype diversity $h$ (Nei, 1987), nucleotide diversity $\pi$ (Nei, 1987) and standard deviations (SD) in parentheses.

\begin{tabular}{|c|c|c|c|c|}
\hline Haplotype & SBA & SKI & PAN & SAL \\
\hline $\mathrm{A}$ & 0.8000 & - & - & - \\
\hline $\mathrm{B}$ & 0.1000 & 0.0909 & - & - \\
\hline $\mathrm{C}$ & 0.1000 & - & - & - \\
\hline $\mathrm{D}$ & - & 0.9090 & - & 0.2000 \\
\hline $\mathrm{E}$ & - & - & 1.0000 & 0.8000 \\
\hline Nucleotide diversity (SD) & $0.000390(0.000392)$ & $0.000128(0.000201)$ & $0.000000(0.000000)$ & $0.000281(0.000357)$ \\
\hline Haplotype diversity (SD) & $0.3778(0.1813)$ & $0.1818(0.1436)$ & $0.0000(0.0000)$ & $0.4000(0.2373)$ \\
\hline
\end{tabular}

SBA - Suche Bagno; SKI - Skieblewo; PAN - Panevezys; SAL - Salcinnikai. 
TABle 4. Polymorphic sites in the $E F-1 \alpha$ gene fragment in genotypes of Oeneis jutta. The entire sequence of genotype A was deposited in GenBank, accession no. GQ351506.

\begin{tabular}{ccccccc}
\hline \multirow{2}{*}{ Haplotype } & \multicolumn{7}{c}{ Nucleotide position } \\
\cline { 2 - 7 } & 280 & 538 & 628 & 658 & 664 & 742 \\
\hline $\mathrm{A}$ & $\mathrm{C}$ & $\mathrm{T}$ & $\mathrm{C}$ & $\mathrm{C}$ & $\mathrm{A}$ & $\mathrm{C}$ \\
$\mathrm{B}$ & $\mathrm{T}$ &. & $\mathrm{T}$ & $\mathrm{T}$ &. & $\mathrm{A}$ \\
$\mathrm{C}$ & $\mathrm{T}$ &. & $\mathrm{T}$ &. & $\mathrm{C}$ & $\mathrm{A}$ \\
$\mathrm{D}$ & $\mathrm{T}$ & $\mathrm{C}$ & $\mathrm{T}$ &. & $\mathrm{C}$ & $\mathrm{A}$ \\
\hline
\end{tabular}

mitochondrial genes (Table 4). A total of six variable nucleotide sites and four genotypes were identified using this gene segment. Both Polish populations and the JON population shared genotype $\mathrm{A}$, whereas unique genotypes were recorded in each of the remaining populations: B in FIN, C in PAN, and D in SAL.

\section{DISCUSSION AND CONCLUSIONS}

The presence of Oeneis jutta in Poland was recorded back in the 20 's of the $20^{\text {th }}$ century (Romaniszyn \& Schille, 1929). These authors reported the presence of the butterfly in the region of the city of Suwałki but did not provide a more precise location of the site where the species was observed. Within the context of the results presented here and the above information, it is difficult to state whether the range of Oeneis jutta in Poland has changed significantly. We do know, however, that currently there are only two isolated sites where this species can be found in Poland, at Skieblewo and in the Suche Bagno nature reserve.

It is also unknown, whether there have been changes in the population size of $O$. jutta at the known sites as there are no earlier studies on the abundance of this butterfly at these sites. At present, we know that the population at Suche Bagno comprises 300-370 individuals. Despite not being able to carry out similar studies at Skieblewo, a similar population size is assumed to occur there. The population of $O$. jutta inhabiting the peatbog near Skieblewo occupies a significantly larger area and is much more dispersed than the population at Suche Bagno.

Analyzing the size of the area where $O$. jutta occurs, its morphological structure, location, and biology indicates that the population at Suche Bagno is isolated and shows little evolutionary development. The peat-bog inhabited by this butterfly fills an elongated basin surrounded by dense woods on all sides, which constitute an impregnable barrier for this butterfly. No $O$. jutta were ever seen in the surrounding woods or dispersing.

The Skieblewo study site is of an entirely different nature. It is a large peat-bog and forest complex, with numerous meadows in the middle of the forest. Here, this butterfly is able to relocate over significant distances, which is possibly why no marked individuals were recorded. Therefore, there is a high possibility for $O$. jutta to extend its habitat into the adjoining marsh forests and peat-bogs at this site.

The analyses of morphological data revealed that the Oeneis jutta populations at Suche Bagno and Skieblewo differ significantly in some morphological characteristics. The distance between the sites, much of which is covered by thick woodland, undoubtedly constitutes an obstacle to the interchange of the individuals between these sites. In effect, this barrier has resulted in the isolation of these populations and the potential loss of intra-population diversity due to inbreeding depression. However, interestingly, higher levels of genetic diversity were observed in the isolated SBA population than in the SKI population in a large forest complex.

The analysis of mtDNA markers revealed a high degree of genetic differentiation between the Polish $O$. jutta populations and the Polish and Lithuanian populations. Such differentiation is likely to result from a historic fragmentation of the populations, subsequent reductions in gene flow, and genetic drift. The fact the SBA and SKI populations, which are relatively closely situated to one another, are very different $\left(\Phi_{S T}=0.69\right)$ indicates a lack of gene flow over a long period of time and/or marked genetic drift. As the overall $\Phi_{S T}$ value recorded in the present study was 0.71 , given the larger geographical distance, this underlines the severity of Polish population subdivision.

Studies on Danish and UK populations of Euphydryas aurinia, another endangered butterfly living in a fragmented habitat, based on allozyme and microsatellite frequencies, revealed a much lower overall $F_{S T}$ value of 0.16 (Sigaard et al., 2008, and references therein). However, another study of the Indonesian Drupadia theda butterfly populations (Fauvelot et al., 2006), based on mtDNA data, revealed $\Phi_{S T}$ values similar to those recorded in our study. Populations sampled from distinct landscapes had $\Phi_{S T}$ values not exceeding 0.65 , yet within regions, none of the pair-wise $\Phi_{S T}$ values were significant.

Differences between populations are more readily detected with mtDNA and more prone to genetic drift than are nuclear loci, an important consideration when sample sizes are limited, which is often the case when studying threatened species. Populations having distinctive allele frequencies, regardless of phylogenetic structure and the level of genetic divergence are defined as demographically independent breeding units and identified as Management Units (MUs; Moritz, 1994). The significance of MUs for conservation is obvious. By defining the appropriate geographic scale for monitoring and management can significantly facilitate the execution of short-term recovery plans for a species. Even though the results presented in the present paper are preliminary and incomplete, because of the lack of a comprehensive comparison of the two peripheral populations in Poland and those in the rest of the species range, they strongly suggest that SBA and SKI populations constitute demographically independent breeding units.

The migratory pattern of species of conservation concern determines the level of gene flow between populations. Even relatively short geographic distances $(10-15 \mathrm{~km})$ can significantly reduce gene flow between populations of sedentary butterflies (Sigaard et al., 2008). Since it is unlikely that the landscape connectivity in the area between the SBA and SKI populations (approximately $30 \mathrm{~km}$ apart) can be increased because of the nature of the intervening environment, gene flow between these populations cannot be improved. Therefore, it is worth considering whether these populations might benefit from "genetic rescue". In many cases, a low level of immigration into small, inbred, at-risk populations has produced fitness benefits by alleviating inbreeding depression (Tallmon et al., 2004). However, immigration of genetically divergent individuals can also lead to the opposite effect: a reduction in population fitness due to out-breeding depression. Thus, it is difficult to predict whether an immigration event will result in a genetic rescue.

ACKNOWLEDGEMENTS. The authors are indebted to P. Ivinskis (Institute of Ecology, Vilnius University, Vilnius, Lithuania) for providing samples from Lithuania and Finland. This research was financed from the Polish Scientific Budget (2006-2009). The support of the Ministry of Science and Higher Education (grant 2 P04F 003 30) is also acknowledged.

\section{REFERENCES}

Altshul S.F., Gish W., Miller W., Myers E.W. \& Lipman D.J. 1990: Basic local alignment search tool. Mol. Biol. 215: 403-410. 
Buszko J. 1993: Motyle dzienne (Rhopalocera). [Daily butterflies.] Atlas Motyli Polski. [Atlas of Butterflies in Poland.] Grupa IMAGE, Warszawa, $269 \mathrm{pp}$.

Buszko J. \& MasŁowski J. 2008: Motyle Dzienne Polski. [Daily Butterflies in Poland.] Kraków, pp. 1-274.

Chapman D.G. 1951: Some properties of the hypergeometric distribution with applications to zoological censuses. Univ. Calif. Publ. Statist. 1: 131-160.

Excoffier L., Smouse P.E. \& Quattro J.M. 1992: Analysis of molecular variance inferred from metric distances among DNA haplotypes: application to human mitochondrial DNA restriction data. Genetics 131: 497-491.

Fauvelot C., Cleary D.F.R. \& Menken S.B.J. 2006: Short-term impact of disturbance on genetic diversity and structure of Indonesian populations of the butterfly Drupadia teda in East Kalimantan. Mol. Ecol. 15: 2069-2081.

Folmer O., Black M.B., Hoch W., Lutz R.A. \& VRijehock R.C. 1994: DNA primers for amplification of mitochondrial cytochrome c oxidase subunit I from diverse metazoan invertebrates. Mol. Mar. Biol. Biotechnol. 3: 294-299.

Gerasimov R.P. \& Plushitch I.G. 2005: Second capture of Oeneis jutta (Lepidoptera, Satyridae) in Ukraine. Vest. Zool. 39(4): 28.

GŁowACIŃSKi Z. (ed.) 2002: Czerwona lista zwierzat ginacych $i$ zagrożonych $w$ Polsce. [Red List of Threatened Animals in Poland.] Instytut Ochrony Przyrody PAN (Department of Nature Conservation PAS), Kraków, 155 pp.

Gıowaciński Z. \& Nowacki J. (ed.) 2004: Polska czerwona księga zwierzat. Bezkregowce. [Polish Red Data Book of Animals. Invertebrates.] Instytut Ochrony Przyrody PAN (Department of Nature Conservation PAS), Kraków, 448 pp.

HaLl T.A. 1999: BioEdit: a user - friendly biological sequence alignment editor and analyses program for Windows 95/98/NT. Nucl. Acids Symp. 41: 95-98.

Hampe A. \& Petit R.J. 2005: Conserving biodiversity under climate change: the rear edge matters. Ecol. Lett. 8: 461-467.

Henriksen H.J. \& Kreutzer I. 1982: Skandinaviens Dagsommerfugle i Naturen. Skandinavisk Bogforlag, Odense, 215 pp.

HewitT G.M. 1996: Some genetic consequences of ice ages, and their role in divergence and speciation. Biol. J. Linn. Soc. 58: 247-276.

Hewitt G.M. 2001: Speciation, hybrid zones and phylogeography - or seeing genes in space and time. Mol. Ecol. 10: 537-549.

HewitT G.M. 2004: Genetic consequences of climatic oscillation in the Quaternary. Phil. Trans. R. Soc. (B, Biol. Sci.) 359: 183-195.
IvinSKis P. \& RimŠAITE J. 2004: Structure and diversity of the butterfly fauna is an index of natural balance. Envir. Res. Engin. Manag. 1(27): 59-64.

KudRnA O. 2002: The distribution atlas of European butterflies. Oedippus 20: 343 pp.

Lesica P. \& Allendorf F.W. 1995: When are peripheral populations valuable for conservation? Conserv. Biol. 9/4: 753-760.

Lukhtanov V.A. \& Eitschberger U. 2000: Butterflies of the World: Nymphalidae V. Oeneis 11: 2, pl. 3/4, f. 1-4.

Mattern D. \& Schlegel M. 2001: Molecular evolution of the small subunit ribosomal DNA in woodlice (Crustacea, Isopoda, Oniscidea) and implications for oniscidean phylogeny. Mol. Phyl. Evol. 18: 54-65.

Monteiro A. \& Pierce N.E. 2000: Phylogeny of Bicyclus (Lepidoptera: Nymphalidae) inferred from COI, COII, and EF-1 $\alpha$ gene sequences. Mol. Phyl. Evol. 18: 264-281.

Ner M. 1987: Molecular Evolutionary Genetics. Columbia University Press, New York, 512 pp.

Romaniszyn J. \& Schille F. 1929: Fauna Motyli Polski. I. [Butterfly Fauna of Poland.] Krakow, 552 pp.

Schmitt T. \& HewitT G.M. 2004: The genetic pattern of population threat and loss: a case study of butterflies. Mol. Ecol. 13: $21-31$.

Schneider S., Roessli D. \& Excoffier L. 2000: Arlequin. A software for population genetic data analysis. Genetics and Biometry Laboratory, University of Geneva, Switzerland.

ScotT J.A. 1986: The Butterflies of North America. Stanford University Press, Stanford, CA, 583 pp.

Sigaard P., Pertoldi C., Madens A., Sogatard B. \& Loeschcke V. 2008: Patterns of genetic variation in isolated Danish populations of the endangered butterfly Euphydryas aurinia. Biol. J. Linn. Soc. 95: 677-687.

Tallmon D.A., Luikart G. \& Waples R.S. 2004: The alluring simplicity and complex reality of genetic rescue. Trends Ecol. Evol. 19/9: 489-496.

Thompson J.D., Gibson T.J., Plewniak F., Jeanmougin F. \& HigGINS D.G. 1997: The ClustalX windows interface: flexible strategies for multiple sequence alignment aided by quality analysis tools. Nucl. Acids Res. 24: 4876-4882.

Vila M. \& BjorkLund M. 2004: The utility of the neglected mitochondrial control region for evolutionary studies in Lepidoptera (Insecta). J. Mol. Evol. 58: 280-290.

Yagi T., Sasaki G. \& Takebe H. 1999: Phylogeny of Japanese papilionid butterflies inferred from nucleotide sequences of the mitochondrial ND5 Gene. J. Mol. Evol. 48: 42-48.

Zhang D.-X., Szymura J.M. \& Hewitt G.M. 1995: Evolution, and structural conservation of the control region of insect mitochondrial DNA. J. Mol. Evol. 40: 382-391.

Received May 12, 2009; revised and accepted September 16, 2009 